\title{
The American Historical Association
}

\author{
Bruce Laurie \\ University of Massachusetts at Amherst
}

The 101 annual meeting of the American Historical Association offered a number of good panels in labor history. Several sessions featured papers on working people in the early modern and modern eras, in the Third World as well as in Europe and the United States. Nearly all presentations bore the influence of the New Labor History, which suggests that the genre no longer confines itself to the familiar industrial worker in modernizing settings.

A session on "Language, Labor, and Ritual: Changes in French Artisan Culture in the Old Regime" heard three papers. John Martin (Trinity University), in a paper titled "Northern Protestants and Popular Heresy in SixteenthCentury Venice' explained why lay and ecclesiastical elites in Venice tolerated Protestants in the middle of the Inquisition. He observed that the city's highly cultivated cosmopolitanism, coupled with fears of disrupting ties with Protestant trading partners, helped stay the hand of repression, but so did the very presence of large communities of French and German Protestants who engaged in craft production. Such artificers not only supplied vital goods and services (printed materials and food being the most obvious) but also developed means of "passing"' as Catholics, feigning devotion to the Church while furtively observing their faith. French masters also figured prominently in a paper by James Farr (University of Tennessee, Knoxville) "Artisans and the New Morality: Sexual Propriety in Dijon during the Catholic Reform (1550-1650).'" Much like Martin, he drew attention to the interior of the artisan community in support of the thesis that the "new sexual morality" was less an imposition from above than a reflection of personal need in the context of increasingly competitive commodity and marriage markets. Farr detected both a heightened proclivity to hurl "sexual slanders" at spouses and daughters and a complementary tendency to defend reputations of female offspring and condemn sexual promiscuity in the name of preserving the order and name of neighborhoods. In " 'Rather than Submit': The Language of Opposition and Honor among Journeyman in Old Regime France,' Cynthia Truant (Newberry Library) reviewed the language of some forty letters written by compagnons to one another and later confiscated by the police. Truant argued that while the documents proved somewhat formulaic and dealt primarily with mundane trade matters, they still shed some light on artisan culture in the transition from an oral culture to a written one. They disclose more concern for honor and disgrace than the ribaldry and opposition to authority that historians 
often associate with French journeyman in this period. Commentator Barbara Diefendorf (Boston University) complimented the authors for their imaginative use of sources, but also raised some useful questions about the sources themselves. She suggested that Truant's materials should be used to counterbalance those that are mediated and perhaps contaminated by official authority. Pursuing this point with regard to Farr's work, she suggested that court records, his chief resource, may reveal more about shifts in legal procedure than changes in popular values. She saw more consistency in the language of insult than Farr indicates and urged him to pursue more compelling evidence of change. In Martin's case, she noted that true religious identity is difficult to determine.

Three papers in the session "New Perspectives on Labor Systems in Northern New Spain in the Seventeenth and Eighteenth Centuries" addressed the mediating force of local conditions and worker agency in the transition from slavery to free labor. A paper by Cheryl English Martin (University of Texas, El Paso), "Labor Relations and Social Control in Eighteenth-Century Chihuahua," looked at miners employed for wages. Her workers proved as independent-minded as those who would work the pits in the United States and Western Europe more than two centuries later. They staged strikes (and sitins!), honored St. Monday, and claimed perquisites unknown to workers in other callings. For a time they enjoyed rights to excess ore and as time wore on, extracted liberal loans in kind from employers (loans that never seemed to secure debt peonage since no one expected repayment, and "debtors" routinely fled with impunity). It was these perquisites, and not wage scales (which were no better than those of other workers) that elevated miners to an early version of a "labor aristocracy." Susan Deeds (Northern Arizona University), who read a paper on "The Persistence of the Labor Repartimiento in Eighteenth-Century Nueva Vizcaya," accounted for the persistence of this "state controlled labor corvée" long after wage babor took elsewhere. In her view, the conjunction of an economic crisis in the 1690s and a diminishing supply of labor, coupled with an alliance of planters, miners, missionaries, and the state, resulted in an agreement to share labor resources under repartimiento. Wage labor developed fitfully in places like Durango but remained subordinate to repartimiento elsewhere well into the eighteenth century. A paper by José Cuello (Marquette University), "From Slavery to Encomienda to Wage Labor in Northwestern Mexico, 1577-1720," endorsed Deed's view of the durability of transitional labor systems. He uncovered considerable overlap among the systems themselves and made a case that encomienda could be and was perfectly compatible with native American cultures that depended on hunting and gathering. Indeed, Spaniards who drew upon seasonal labor encouraged nomadism. In his comments, James Riley (Catholic University of America) stressed the contradictory elements of Spanish culture: an intense ethnocentrism, a belief in hierarchy and fear of freedom on the one hand, and 
a kind of pragmatism on the other. In northern Mexico, these made Spanish rule uniquely harsh but also more flexible. There the conquerors confronted different Indian societies and cultures so that the labor systems that emerged resulted from a series of "negotiated compromises."

David Zonderman (Yale University) and Teresa Murphy (University of Rhode Island) read papers on "Church and Community among Antebellum Working People in New England." Zonderman found that small-town textile entrepreneurs contrived to blend the spatial and structural elements of the traditional New England village into their communities, both planned and unplanned, in a search for a "middle ground" between the agrarian past and the industrial present. Some workers saw this environment as a screen for exploitation, but most embraced it as a favorable alternative to both the sleepy farming community and the bustling industrial city. Murphy employed the New England Workingmen's Association as a point of departure to explore the social meaning imparted by the new evangelicalism in the 1840s. Informed as it was by the tenet of "free agency," this creed was a mixed legacy that armed workingmen and women with a stinging moral critique of industrial capitalism on the one hand, but placed restrictions on tactical imaginations on the other. Evangelicals rejected politics as "corrupt" and strikes as "coercive," and thus proved reluctant to seek reform at the polls or redress through collective action on the job. Commentator Jonathan Prude (Emory University) took both papers to be interesting and important statements of the New Labor History, praising both authors for refusing to treat culture as a mere reflection of economic interest. He urged Murphy, however, to chart the development of evangelicalism since the days of Jacksonian laborite Seth Luther in the 1830s and pressed her to consider the gender dimension, suggesting that women may have experienced religion in unique ways. He went on to argue that Zonderman assumed a common discourse instead of demonstrating it and concluded that the shared vision of the "middle landscape" still had room for ambiguity and conflicting interpretation. In his comments, Bruce Laurie (University of Massachusetts, Amherst) argued that Zonderman's industrialists, much like many modern-day historians, had a distorted view of the colonial village. He cited recent investigations by historical geographers, which indicate that such places evinced scattered settlement, not the nucleated "peaceable kingdoms" reconstructed by Samuel Slater and his colleagues. He conceded that compliant workers may have preferred the textile village over the metropolis but argued that dissident operatives were more impressed by the drudgery of the new regime. He found Murphy's formulation more promising and averred that it may help explain why it was that New England workers, having mounted a bitter rhetorical assault on the factory and reached a high level of organization in the 1840 s, were less inclined to strike than the men and women who inaugurated the region's labor movement a decade before.

James Jaffe (State University of New York, Purchase), John Kulczycki 
(University of Illinois, Chicago), and Carl Strikwerda (University of California, Riverside) read papers in a session titled "Coal Miners and Working-Class Militancy in Western Europe." Jaffe used a colliery strike on the Tyneside in 1831 to contest the widely held view that English workers of the 1830s and 1840s were "impractical visionaries." He showed that work stoppage arrayed sophisticated owners who had worked out a cartel-like arrangement against equally sophisticated workers who had negotiated qualified guarantees of full employment. For their part, the miners looked to push forward the frontiers of control in 1831 by demanding "certification", of their numbers in an attempt to exercise more leverage over the labor supply. This "worker regime" ended within a year but indicated that workers were both "radical and practical." Kulczycki looked at the formative forces behind Polish unions in the Ruhr mines at the turn of this century. He found that such workers were driven to organize separately because German co-workers, both centrist and socialist, consistently ignored their linguistic and other unique needs and not because of their own nationalist sensibilities. German ethnocentrism, he concluded, inspired a Polish equivalent. Strikwerda traced the sources of mine workers' weakness and strength in the realm of unionism from the 1870 s to the eve of World War I in the Liege basin. Early on, the combination of industrial decline, employer paternalism, and miner socialism that stressed political action over unionism doomed colliery strikes to defeat after defeat.

Effective unionism awaited the eve of the war, when the economy picked up, conglomerates emerged, and miners split into two factions, one of which hewed to the old parochial socialism while the other rejected radicalism for industrial unionism and cultivated alliances with metal workers and with cooperatives and insurance societies that helped break the hold of employer paternalism. Commentator Michael Hanagan (Columbia University) found Kulczycki's ethnic argument to be "incomplete" and proferred a demographic point based on the fact that Polish miners were transients with special interests. As a case in point, he cited an 1899 strike that saw them leave their jobs in protest against a new levy for pensions, a benefit that meant little to them but quite a bit to German resident workers. He also encouraged Strikwerda to assess the demographic dimension to his story by raising the possibility that the minermetal worker axis may have hinged in part on workers who ebbed and flowed between mine and metal mill, a common pattern across Western Europe. He went on to suggest that the factional struggle may have pitted competing expressions of socialism against one another, because the industrial unionists may have been socialists themselves. Louise Tilly (New School for Social Research) drew attention to larger themes raised by the papers: the relationship between class composition or cohesion and worker militancy; the place of employers in working-class historiography; and the question of capital and the state. For the first, she found no easy correlation between the propensity to strike and the level of class solidarity. She applauded each author for bringing 
employers into sharper relief. And she observed that Jaffe's paper demonstrated that the state can be something of an independent force that does not automatically do capital's bidding, adding, "So much for bourgeois hegemony."

Thinking over the broader implications of these papers brought to mind the late Herbert Gutman's observation that his study of chattel slavery enlarged and sharpened the questions he asked of wage workers. As a historian of nineteenth-century artisans in the U.S., I had a similar reaction to the presentations on European miners and especially those on labor systems in Colonial Mexico-systems not far removed from Gutman's slaves-for as a matter of course each moved easily from the contours of workers' culture to class relations and to relations between classes and government in an integrative approach often lacking in American working-class historiography. We Americanists have much to learn from our European and Latin American colleagues. 